\title{
RISK ASSESSMENT IN NON-STANDARD FORMS OF CIVIL ENGINEERING CONSULTING SERVICES
}

\author{
WM Sarath C PIYADASA, Bonaventura H. W. HADIKUSUMO \\ Department of Construction, Engineering and Infrastructure Management, \\ Asian Institute of Technology, Pathumthani, Thailand
}

Received 16 Feb 2012; accepted 17 Apr 2012

\begin{abstract}
Although a large body of research exists on risk assessment in civil engineering projects and of owners, contractors, concessionaires and financiers of such projects, there is a lacuna in such research on engineering consultants, particularly those associated with non-standard forms of consulting services. This paper seeks to explore the genesis of the underlying risks in non-standard forms of engineering consulting services, systematically classify the risks, and develop a Risk Breakdown Structure and a generic Framework for efficient assessment of these risks, which is a prerequisite for sound risk management in the engineering consulting industry. The research adopts a mixed method approach, synthesising exploratory type multiple-case studies and questionnaire surveys, carried out in 14 engineering consulting firms having extensive experience in the delivery of non-standard consulting services. This paper provides empirical insights of the genetic makeup of risks associated with non-standard forms of consulting services. Such risks are found to be predominantly linked to design office based activities that underline the importance of design function in engineering consulting practice. Loss of reputation and/or goodwill is rated as the most severe potential impact on consultants. Proposed Risk Assessment Framework provides the engineering consulting industry with a functional tool for efficient risk management.
\end{abstract}

Keywords: engineering consulting services, risk assessment, project delivery methods, case studies.

\section{Introduction}

\section{Risk in engineering consulting services}

Risk is inherent in every business enterprise and engineering consulting is no exception. Risk is not new to the consulting industry; what is new is its evolving complexity and intensity. Many facets of engineering consulting services such as planning, design, inspection and certification are potential sources of risks for consultants. Due to these complexities, engineering consultants face an array of risks peculiar to the industry.

The law places on engineering consultants an increasing duty of care towards those who rely on their advice and skill. In the performance of their obligations, consultants are expected to carry out commissions with due diligence and care, and required to possess and exercise level of skill and judgment in accordance with prevailing standard of the profession (World Bank 2004). Kardon (2005) opines that engineering consultant's services need not be perfect, and not necessarily expected to be the highest exemplar of his profession. However, the services must meet a certain minimum level of expertise. A consultant is not necessarily negligent because he errs in judgment or his efforts prove unsuccessful. However, consultant's negligence may be established if such an error in judgment or lack of success is due to a failure to fulfil the required duty of care. Consultants carry unlimi- ted liability as governed by the applicable law, in the case of gross negligence or wilful misconduct on their part.

\section{Non-standard forms of engineering consulting services}

There had been a worldwide dissatisfaction among owners with the way construction industry implements projects, particularly the fragmented and adversarial approach of the standard Design-Bid-Build (DBB) method, characterised by recurrent cost and time over-runs. Moreover, governments all over the world are gradually moving towards private sector participation in the financing of large infrastructure projects.

Some of the alternative project delivery methods that have emerged in response to these challenges are:

Integrated - Design-Build (DB), Turnkey (TK), Engineer-Procure-Construct (EPC), Early Contractor Involvement;

Management - Agency Construction Management (CMA), Construction Management at Risk (CMR), Management Contract (MC);

Relational - Partnering, Alliancing, Joint Ventures, Consortia; and

Concessions - Build-Own-Operate (BOO), Build-OperateTransfer (BOT), Design-Build-Operate (DBO), Design-Build-Finance-Operate (DBFO) and other variants. 
A number of research on the comparative performance of different project delivery methods in relation to time and cost over-run, supports the superiority of nonstandard methods over standard Design-Bid-Build method; most recent such study being by Ojo et al. (2011). This trend towards alternative project delivery methods is driving the engineering consulting industry to venture into non-standard forms of services.

\section{Risk landscape in non-standard forms of consulting services}

In this research, innovative consulting services pertain to alternative project delivery methods, as distinct to standard Design-Bid-Build, are considered as non-standard forms of consulting services. Alternative project delivery methods organise the construction process differently and allocate risks differently among the project team, including the consultant.

Non-standard forms of consulting services entail consultants to deliver new types of services and assume atypical risks. Unwillingness to take on risks outside the consultant's core activities would inevitably lead to loss of business opportunities. Jaafar et al. (2008) have dealt extensively with the current competitive business environment prevailing in the engineering consulting industry.

This trend of increasing exposure to atypical risks in non-standard forms of services is evident from the increasing worldwide incidence of professional liability actions by clients/owners, contractors and third parties (Yisa, Edwards 2002). Frivolous lawsuits compel consultants to commit valuable resources in needless litigation. A liability claim, even if successfully defended can be very costly and a huge distraction to a consultant (FIDIC 1997).

\section{Background}

\subsection{Overview of the risk management process}

In practice, a two phased approach comprising of risk assessment and risk response is preferred in risk management. The risk assessment phase encompasses risk identification, qualitative/quantitative risk analysis and prioritisation (Halman, Weijden 1997). Once risks are identified, analysed and prioritised, the risk management process could progress to the final phase of risk response that encompasses risk response planning, risk allocation and risk monitoring (PMBOK Guide 2008). The objective of risk response is to establish a strategy to mitigate potential threats and enhance potential opportunities. However, every potential risk does not warrant a response. While some risks may justify a response, "do nothing" may be the rational decision for others. It is important to note that risks are affected by risk responses only (Artto 1997).

Macneil (cited in Rahman, Kumaraswamy 2004) emphasise the fact that all possible risks are not foreseeable at the inception. It is likely that even the foreseen risks may change in importance subsequently. Also, certain risk factors may influence others, requiring continuous monitoring and adjustments to risk management strategies.

\subsection{Risk assessment}

Risk assessment, a pre-requisite in the risk management process may be defined as the integrated analysis of the risks inherent in a system and their significance in an appropriate context. The level of risk is based on both likelihood of risk and its severity. The assessment of the level of risk is a complex process and this complexity arises from the subjective opinions and imprecise quantification of likelihood and severity.

Identification of risks is considered as the most critical element of risk assessment, as risks cannot be eventually managed unless identified (Hansen, Millar 1997). The key point in risk assessment is to use ranking techniques where major potential risks are given higher priority than minor ones (Zavadskas et al. 2010).

\subsection{Risk classification}

Risk classification is an important step in the risk assessment process, as it attempts to structure the diverse risks that have been identified (Tah, Carr 2001). There are varieties of approaches for classifying the identified risks. A Risk Breakdown Structure is one approach to provide such a structure (PMBOK Guide 2008). In this research, risks are classified according to a hierarchical Risk Breakdown Structure comprising of Risk Categories, Risk Factors and Risk Attributes, based on their origin and location of impact. Each Risk Factor consists of a number of Risk Attributes.

The distinction made here between risks and Risk Factors is that risks are triggered by Risk Factors. Risk Factors do not affect the consultants directly but do so through ensuing risks. In thinking about risks, it is easier to think of the presence of individual influencing factors, as they can be individually assessed with a limited amount of vague information (Tah, Carr 2001). Kim (2010) has applied Risk Factors in the development of a performance management method in construction business.

\section{Research methodology}

The objectives of this research are to:

-Investigate the risk exposure in civil engineering consulting, with emphasis on risk exposure in nonstandard forms of services;

- Identify significant Risk Categories, Risk Factors and Risk Attributes that constitute a comprehensive Risk Breakdown Structure; and

- Develop a Risk Assessment Framework.

"Mixed methods" of research design that combines different techniques into a single research was adopted. Mixed methods research can permit investigators to address more complicated research questions and collect a richer and stronger array of evidence than can be accomplished by any single method alone (Yin 2009). Case studies were used as the primary method, complemented by questionnaire surveys.

Ten consulting firms from Thailand (of which three are subsidiaries of large international firms) and four from Sri Lanka participated in this research (Table 1). Senior 
management of consulting firms having extensive experience in non-standard consulting services formed the principal respondents/interviewees.

In the selection of firms, attention was paid to encompass diversity of contexts and environments.

Research questionnaire was developed based on the initial interviews carried out with experienced practitioners from three consulting firms. It was pilot tested with another firm and further refined prior to using in the questionnaire survey. The questionnaire was administered to senior management of 11 firms, out of the 14 firms participated in this research.

The questionnaire was divided into three sections. The first section required respondents to provide information on their professional career. The second section sought information on experience of the firm in non-standard forms of consulting services. In the third section which formed the main questionnaire, respondents were required to assess the importance of each identified Risk Attribute on the basis of likelihood and severity of the ensuing risk, and translate their assessment into an overall importance rating on a five point rating scale: "extremely important" (5), "very important" (3), "important" (2), "fairly important" (1) and "not important" (0). A sample of the score sheet for a Risk Factor is presented in Table 2.

The 109 Risk Attributes included in the questionnaire were ranked in the order of the scores and selected for inclusion in the Risk Breakdown Structure, based on following criteria:
- Three highest ranking Risk Attributes from each Risk Factor; and

-Risk Attributes having a score equal to or exceeding the median score of 35 (out of a maximum of 55 from 11 questionnaires).

Ranking of the Risk Attributes associated with a Risk Factor is presented in Table 3. The attributes that met these criteria and selected for inclusion in the Risk Breakdown Structure are shown in bold.

Questionnaire survey was followed by exploratory type multiple-case studies. The multiple-case study design was based on single unit of analysis (holistic), the unit of analysis being consulting firm. The evidence from multiple cases is considered more compelling, and overall study is therefore regarded as being more robust (Herriot, Firestone 1983, cited in Yin 2009).

A Case Study Protocol was formulated on the lines recommended by Yin (2009), prior to commencement of data collection activities. Face-to-face interviewing of senior management of consulting firms in the form of semi-structured interviews, and review of firm's records and industry publications formed the principal methods of data collection. Cross-case analysis and synthesis was performed in the analysis phase of the multiple-case studies, following the cross-case procedure for developing theme based assertions (Stake 2006). The quality of the research design as indicated by measures such as Construct Validity, External Validity and Reliability was enhanced by the use of triangulation techniques and multiple data sources, and also by minimising interview bias.

Table 1. Participating consulting firms in the research

\begin{tabular}{|c|c|c|c|}
\hline $\begin{array}{c}\text { Case } \\
\text { Number }\end{array}$ & Description of Consulting Firm & $\begin{array}{l}\text { Position of Principal } \\
\text { Interviewee in the Firm }\end{array}$ & $\begin{array}{l}\text { Typical Non-Standard Consultancy Service Per- } \\
\text { formed by the Firm (Reviewed in Case Study) }\end{array}$ \\
\hline 1 & Multi-disciplinary firm & Executive Director & $\begin{array}{l}\text { Consultant to Owner in a Turnkey wastewater } \\
\text { treatment project in Thailand }\end{array}$ \\
\hline 2 & $\begin{array}{l}\text { Subsidiary of an international multi- } \\
\text { disciplinary firm }\end{array}$ & Managing Director & $\begin{array}{l}\text { Consultant to Owner in a Design-Build water } \\
\text { treatment project in Thailand }\end{array}$ \\
\hline 3 & $\begin{array}{l}\text { Firm specialised in Transportation } \\
\text { engineering }\end{array}$ & Senior Manager & $\begin{array}{l}\text { Designer to Design-Build Contractor in a bridge } \\
\text { construction project in Cambodia }\end{array}$ \\
\hline 4 & $\begin{array}{l}\text { Firm specialised in Water Resources } \\
\text { engineering }\end{array}$ & Managing Director & $\begin{array}{l}\text { Consultant to Owner in a Turnkey weir construc- } \\
\text { tion project in Thailand }\end{array}$ \\
\hline 5 & Multi-disciplinary firm & Chairman & $\begin{array}{l}\text { Consultant to Owner in a Turnkey project for } \\
\text { hazardous waste water treatment in Thailand }\end{array}$ \\
\hline 6 & Multi-disciplinary firm & Managing Director & $\begin{array}{l}\text { Consultant to Owner in a Turnkey project for } \\
\text { waste water treatment in Thailand }\end{array}$ \\
\hline 7 & Multi-disciplinary firm & Managing Director & $\begin{array}{l}\text { Construction Management Consultant to Owner } \\
\text { in a waste water treatment project in Thailand }\end{array}$ \\
\hline 8 & International multi-disciplinary firm & Director & $\begin{array}{l}\text { Designer to Design-Build Contractor in a Mass } \\
\text { Transit project in Thailand }\end{array}$ \\
\hline 9 & $\begin{array}{l}\text { Multi-disciplinary firm with in-house } \\
\text { EPC unit }\end{array}$ & General Manager & $\begin{array}{l}\text { Designer to Design-Build Contractor in a waste } \\
\text { water treatment project in Sri Lanka }\end{array}$ \\
\hline 10 & Specialised Design firm & Managing Director & $\begin{array}{l}\text { Designer to Build-Own-Operate Concessionaire } \\
\text { in a thermal power project in Sri Lanka }\end{array}$ \\
\hline 11 & $\begin{array}{l}\text { Firm specialised in Environmental } \\
\text { engineering }\end{array}$ & Managing Director & $\begin{array}{l}\text { Designer to Design-Build Contractor in a } \\
\text { wastewater treatment project in Sri Lanka }\end{array}$ \\
\hline 12 & $\begin{array}{l}\text { Firm specialised in Project Manage- } \\
\text { ment }\end{array}$ & Managing Director & $\begin{array}{l}\text { Project Management Consultant to Owner in a } \\
\text { Design-Build industrial project in Sri Lanka }\end{array}$ \\
\hline 13 & International multi-disciplinary firm & Country Manager & - \\
\hline 14 & International multi-disciplinary firm & Chief Executive Officer & - \\
\hline
\end{tabular}


Table 2. Sample results of questionnaire survey

Risk Factor (A1) - Quality of Services

\begin{tabular}{|c|c|c|c|c|c|c|c|c|c|c|c|c|}
\hline $\begin{array}{l}\text { Risk Attribute } \\
\text { Code }^{*}\end{array}$ & $\vec{\Xi}$ & $\underset{\Xi}{\stackrel{\Xi}{\Xi}}$ & $\stackrel{n}{\Xi}$ & $\underset{\Xi}{\stackrel{\Xi}{\Xi}}$ & 吅 & $\begin{array}{l}0 \\
\Xi \\
\Xi\end{array}$ & $\stackrel{\infty}{\Xi}$ & $\stackrel{\Xi}{\Xi \Xi}$ & $\begin{array}{l}\stackrel{0}{ } \\
\text { 国 }\end{array}$ & $\begin{array}{l}\Xi \\
\Xi \\
\Xi\end{array}$ & $\underset{\Xi}{\stackrel{ }{\Xi}}$ & $\begin{array}{l}\stackrel{0}{0} \\
\mathscr{U} \\
\frac{\pi}{0} \\
0\end{array}$ \\
\hline$A 101$ & 5 & 5 & 5 & 5 & 5 & 3 & 5 & 5 & 5 & 1 & 5 & 49 \\
\hline A102 & 3 & 3 & 3 & 5 & 3 & 3 & 3 & 3 & 5 & 2 & 5 & 38 \\
\hline$A 103$ & 3 & 3 & 2 & 3 & 5 & 2 & 3 & 5 & 5 & 5 & 5 & 41 \\
\hline A104 & 2 & 3 & 2 & 3 & 3 & 2 & 1 & 5 & 5 & 3 & 5 & 34 \\
\hline$A 105$ & 2 & 3 & 3 & 2 & 3 & 5 & 1 & 5 & 5 & 5 & 5 & 39 \\
\hline A106 & 3 & 3 & 3 & 3 & 3 & 3 & 2 & 3 & 5 & 2 & 3 & 33 \\
\hline$A 107$ & 2 & 3 & 3 & 1 & 3 & 5 & 3 & 3 & 5 & 3 & 5 & 36 \\
\hline A108 & 2 & 3 & 1 & 1 & 3 & 5 & 1 & 2 & 2 & 5 & 5 & 30 \\
\hline A109 & 3 & 3 & 2 & 1 & 3 & 5 & 2 & 3 & 5 & 2 & 3 & 32 \\
\hline A110 & 2 & 3 & 3 & 1 & 3 & 3 & 2 & 3 & 5 & 2 & 5 & 32 \\
\hline A111 & 2 & 3 & 2 & 2 & 3 & 3 & 3 & 3 & 3 & 3 & 5 & 32 \\
\hline A112 & 2 & 3 & 3 & 3 & 3 & 3 & 3 & 3 & 2 & 3 & 3 & 31 \\
\hline
\end{tabular}

*For description of the Risk Attributes, please refer Table 3.

Table 3. Sample of ranking of Risk Attributes

Risk Factor (A1) - Quality of Service

\begin{tabular}{l|l|c}
\hline Code & \multicolumn{1}{|c}{ Risk Attribute } & Ranking \\
\hline A 101 & Design errors or omissions affecting safety & 1 \\
\hline A 103 & Non-compliance with Regulations & 2 \\
\hline A 105 & Use of inappropriate Specifications, Standards & 3 \\
\hline A 102 & Design errors or omissions adversely affecting costs/benefits & 4 \\
\hline A 107 & Failure to foresee relevant factors affecting the designs & 5 \\
\hline A 104 & Incorrect interpretation of Specifications, Standards & 6 \\
\hline A 106 & Poor communications within the project team & 7 \\
\hline A 109 & Lack of experienced and skilled staff & 8 \\
\hline A 110 & Poor quality of drawings, insufficient level of detailing & 8 \\
\hline A 111 & Infringement of copyrights & 8 \\
\hline A 112 & Constructability problems & 11 \\
\hline A 108 & Conflicts and incompatibility among documents & 12 \\
\hline
\end{tabular}

\section{Analysis and findings}

\subsection{Responses to research questions}

This research addressed the following six Research Questions. Ratings of expected utility of each Case for developing responses to the Research Questions are presented in Table 4. Few negative responses received are shown as "Atypical".

Responses to each Research Question emerged from the multiple-case studies are discussed below:

Research Question 1 - How does risk in non-standard forms of consulting services differ from standard forms of consulting services? Is the perceived overall risk level higher in non-standard forms of consulting services?

Response: The multiple-case studies comprising of 14 cases indicated an increasing preference of owners for alternative project delivery methods, influenced by unfavourable past experiences of recurrent time and cost over- runs identified with the standard Design-Bid-Build method. These alternative project delivery methods which are inherently more complex in their organisation necessitate non-standard forms of consulting services.

Such services expose the consultants to atypical risks, in addition to the risks present in standard consulting services. For example, in one Case where the client was a manufacturing company, the consulting firm was required to provide a performance guarantee. In another Case where the client was a concessionaire company, the consulting firm was offered their fees in the form of shares in the concessionaire company, instead of in cash.

Cross-case analysis of the multiple-case studies pointed to:

-A trend of escalation of overall risk level in Civil engineering consulting industry in general; and

- Comparatively higher levels of risk exposure under non-standard forms of consulting services. 
Table 4. Ratings of expected utility of each case for research questions

\begin{tabular}{|c|c|c|c|c|c|c|}
\hline \multirow[b]{2}{*}{ Case No. } & \multicolumn{6}{|c|}{ Utility of Cases for Addressing Research Questions } \\
\hline & 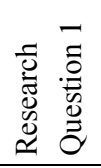 & 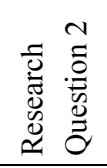 & 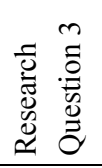 & 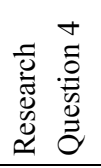 & 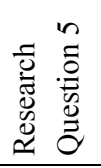 & 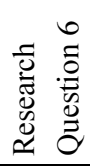 \\
\hline Case 1 & $\mathrm{H}$ & $\mathrm{H}$ & $\mathrm{M}$ & $\mathrm{H}$ & $\mathrm{H}$ & $\mathrm{M}$ \\
\hline Case 2 & ATYP & ATYP & $\mathrm{H}$ & $\mathrm{H}$ & $\mathrm{H}$ & $\mathrm{H}$ \\
\hline Case 3 & $\mathrm{H}$ & $\mathrm{H}$ & $\mathrm{H}$ & $\mathrm{M}$ & $\mathrm{H}$ & $\mathrm{M}$ \\
\hline Case 4 & $\mathrm{H}$ & $\mathrm{H}$ & $\mathrm{H}$ & $\mathrm{M}$ & $\mathrm{H}$ & $\mathrm{M}$ \\
\hline Case 5 & $\mathrm{M}$ & $\mathrm{H}$ & $\mathrm{M}$ & $\mathrm{H}$ & $\mathrm{H}$ & $\mathrm{H}$ \\
\hline Case 6 & $\mathrm{H}$ & $\mathrm{L}$ & $M$ & $\mathrm{M}$ & $\mathrm{H}$ & $\mathrm{L}$ \\
\hline Case 7 & $\mathrm{H}$ & $\mathrm{M}$ & - & - & - & $\mathrm{H}$ \\
\hline Case 8 & $\mathrm{M}$ & $\mathrm{M}$ & $\mathrm{H}$ & $\mathrm{H}$ & $\mathrm{H}$ & $\mathrm{H}$ \\
\hline Case 9 & $\mathrm{H}$ & $\mathrm{H}$ & $\mathrm{M}$ & $\mathrm{H}$ & $\mathrm{H}$ & $\mathrm{H}$ \\
\hline Case 10 & $\mathrm{H}$ & $\mathrm{H}$ & $\mathrm{H}$ & $\mathrm{M}$ & $\mathrm{H}$ & $\mathrm{H}$ \\
\hline Case 11 & $\mathrm{M}$ & $\mathrm{M}$ & $\mathrm{H}$ & $\mathrm{H}$ & $\mathrm{H}$ & $\mathrm{M}$ \\
\hline Case 12 & $\mathrm{H}$ & $\mathrm{H}$ & $\mathrm{H}$ & $\mathrm{M}$ & $\mathrm{H}$ & $\mathrm{H}$ \\
\hline Case 13 & $\mathrm{H}$ & $\mathrm{H}$ & - & - & - & $\mathrm{H}$ \\
\hline Case 14 & $\mathrm{H}$ & $\mathrm{H}$ & - & - & - & $\mathrm{H}$ \\
\hline
\end{tabular}

Note: H - High Utility; M - Medium Utility; L - Low Utility; ATYP - Atypical.

One indicator of this trend emerged from the multiple-case studies is the increasing incidences of disputes and professional liability actions against consultants, by clients/owners, contractors and Third Parties.

Research Question 2 - What are the underlying causes for higher level of risk in non-standard forms of consulting services?

Response: One of the most common causes for higher level of risk, cited by the participants of the case study was the gradual expansion of the scope of consultant's services by clients, beyond the original scope in the consultancy contract. In 10 out of the 14 Cases, consultants were compelled to deliver additional services in the form of study of alternatives, design changes, preparation of additional drawings, cost estimates, extended supervision, etc. without additional remunerations.

Nine Cases cited the client's use of inappropriate contract forms that have been originally drafted for standard consultancy services, with ad hoc modifications. Use of such forms that are ill equipped to meet the contingencies in non-standard consulting services would severely curtail the consultant's ability to seek remedies under the consultancy contract.

Another common cause cited by nine Cases was the inclusion of an unlimited liability clause in the consultancy agreement by clients. In standard consultancy services, the norm is to limit the consultant's liability to $100 \%$ of the fees. Unlimited liability provision could ruin a consulting company, even if covered under a Professional Indemnity insurance policy.

Seven cases cited financial stability of the clients, who may be concessionaires/financiers/contractors of projects and not necessarily the owners of projects the consultants are accustomed to serve. In the event of financial difficulty of the client of a non-standard service, the con- sultant may be the most financially vulnerable party among the project team.

In addition to above, the Cases attributed the following characteristics peculiar to non-standard forms of consulting services, to the higher risk level prevalent in such services:

- Lack of mature Legal/commercial framework to meet contingencies of such consulting services;

-Increasing complexity of construction project organisation;

- Increasing complexity of consultant's own organisation owing to growing demand for integrated service delivery, necessitating in-house multi-disciplinary professional teams that are not within the consultant's area of expertise;

-Unilateral transfer of some of the project risks hitherto carried by clients to consultants, without commensurate risk premium; and

-Limited exposure to non-standard forms of consulting services.

Research Question 3 - What is the most appropriate primary classification of risk in non-standard forms of consulting services?

Response: Literature review and exploratory interviews with senior management of selected consulting firms pointed to following three categories of risks as the most appropriate:

- Internal Risk - arising from the management of internal resources of consultants. These are within the consultant's organisational environment such as management style, rules, policies, processes, structures, decisions, cultures, experience in similar type of work, adequacy of human and financial resources and in-house technical capacity (Barber 2005). Inter- 
nal Risks are to a large extent manageable by the consultants;

-Operational Risk - arising from the structure of construction industry such as market conditions, business practices, Legal system and Regulatory regimes applicable to consulting industry. All consultants operating in a particular market are exposed to same risks, albeit to different degrees. Consultants have minimal control over Operational Risk;

- Project Risk - arising from project characteristics such as project owner, project delivery method, adequacy of financing, complexity of project, speed of implementation, physical location, vulnerability to natural disasters and other Force Majeure events. Consultants have limited control over Project Risk.

These three Risk Categories constitute the first tier of the classification of risks in the proposed Risk Breakdown Structure depicted in Figures 1, 2 and 3.

Research Question 4 - What are the most significant Risk Factors associated with each Risk Category?

Response: Literature review and exploratory interviews with senior management of selected consulting firms led to selection of:

- Six significant Risk Factors under the Risk Category - Internal, depicted in Figure 1;

-Four significant Risk Factors under the Risk Category - Operational, depicted in Figure 2; and

- Nine significant Risk Factors under the Risk Category - Project, depicted in Figure 3.

These 19 Risk Factors constitute the second tier in the proposed Risk Breakdown Structure.

Research Question 5 - What are the most significant Risk Attributes associated with each Risk Factor?

Response: The 109 Risk Attributes included in the questionnaire were ranked in the order of the scores and 74 were selected for inclusion in the Risk Breakdown Structure, based on the criteria given in Section 2.

Accordingly, 20 Attributes of Internal Risk, 17 Attributes of Operational Risk and 37 Attributes of Project Risk were selected. These 74 significant Risk Attributes constitute the third tier of the proposed Risk Breakdown Structure.

Research Question 6 - How are the identified significant Risk Factors/Risk Attributes contribute to the impact of risk?

Response: An important outcome of the multiple-case studies is the delineation of mechanisms for impact of risk, under each of the three Risk Categories viz. Internal, Operational and Project. Findings from the cross-case analysis pointed to following significant modes for impact of risk:

- Loss of reputation and/or goodwill;

- Claims/litigation by client/owner;

- Claims/litigation by contractor;

- Legal/Statutory liabilities (including liabilities to Third Parties); and

-Financial loss.
Generating research findings from the responses to Research Questions, based on the methodology developed by Stake (2006) is presented in Table 5.

\subsection{Development of risk assessment framework}

Risk Assessment Framework was developed with the objectives of:

-Explaining the genetic makeup of risks associated with non-standard forms of consulting services and their impact; and

- Identification, analysis and prioritisation of Risk Factors/Risk Attributes to facilitate the final phase of risk management, viz. risk response, of commissions undertaken by consultants.

The hierarchically structured Risk Breakdown Structure developed for the three Risk Categories Internal, Operational and Project depicted in Figures 1, 2, and 3 respectively, constitute the pillars of the proposed Risk Assessment Framework. The 19 Risk Factors and 74 Risk Attributes that are found to be significant constitute this Framework, presented in Figure 4, in conjunction with Figures 1, 2 and 3. Each Risk Category is influenced by its own operating environment viz. Organisational, External and Project; and dominated by different players, as depicted in Figure 4. The numerical code attached to each Risk Factor denotes the mode of impact of the ensuing risk.

It is evident from the Risk Attributes constituting the Risk Assessment Framework that Project Risks dominate the risk landscape, closely followed by Internal Risks. Of the Project Risks, significant Risk Attributes are of diverse origin. In contrast, the Internal Risks are to a large extent concentrated around design office related Risk Attributes such as design errors or omissions affecting safety, designs not meeting owner's requirements, delays in issue of drawings, design errors or omissions affecting costs/ benefits and failure to foresee relevant factors affecting the designs. The importance of design function in engineering consultants has been emphasized by Tang et al. (2009). This finding underlines the need for unrelenting attention to the design office function by the consultants.

\subsection{Practical application of the risk assessment framework}

In practice it may not be possible to deal with a large number of Risk Factors/Attributes in the risk management of a given consultancy commission; hence selection of a manageable number of most significant Risk Factors/Attributes from each of the three Risk Categories by ranking on the basis of the level of ensuing risk is recommended.

Initially, all Risk Factors/Attributes depicted in Figures 1, 2 and 3 under the three Risk Categories are to be considered and the level of each ensuing risk is to be rated on the basis of:

- Likelihood of risk, influenced by applicable organisational/external/project environments; and

- Severity of risk influenced by the mode of impact of the risk.

Each risk may be rated on the basis of the product: 


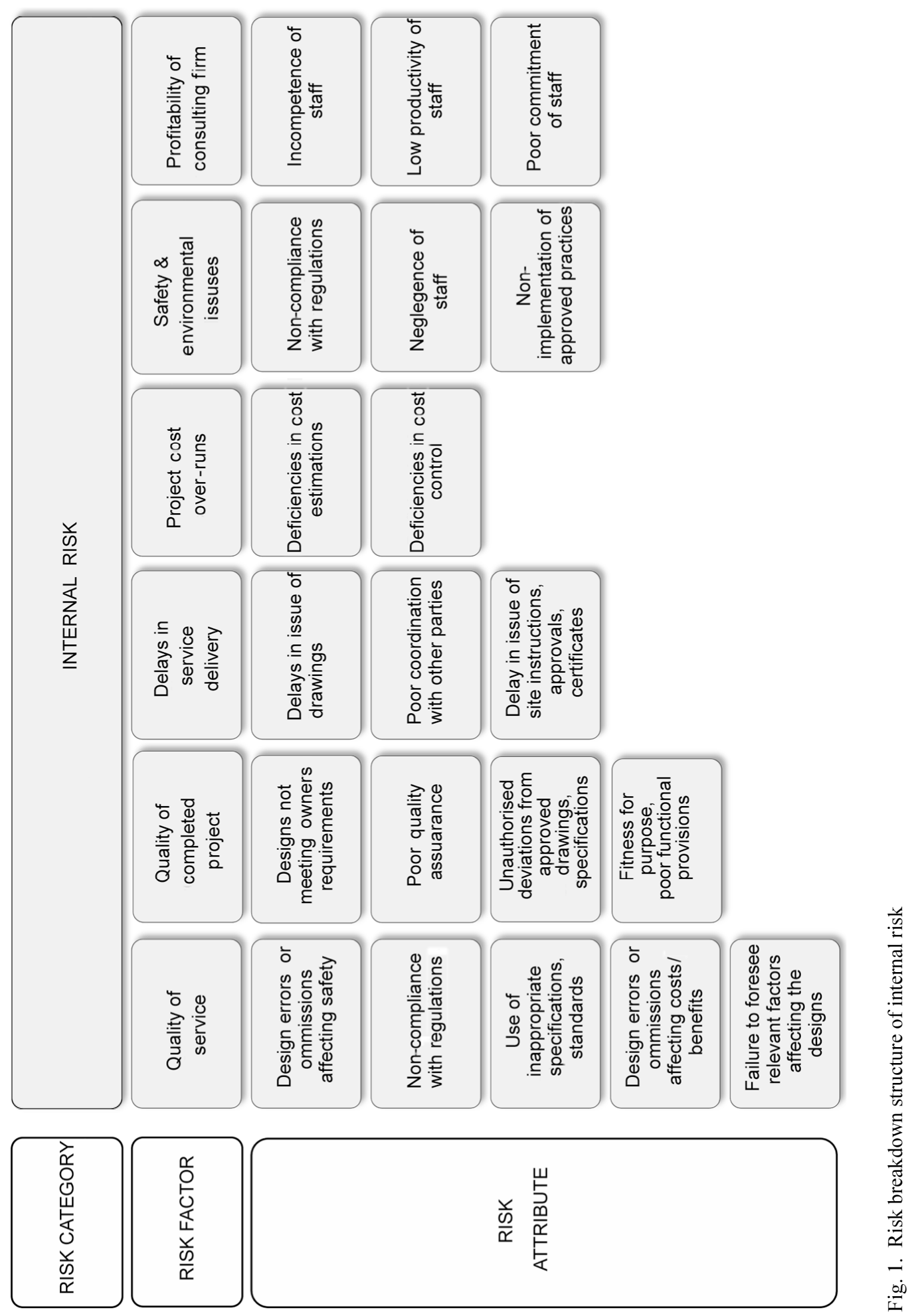




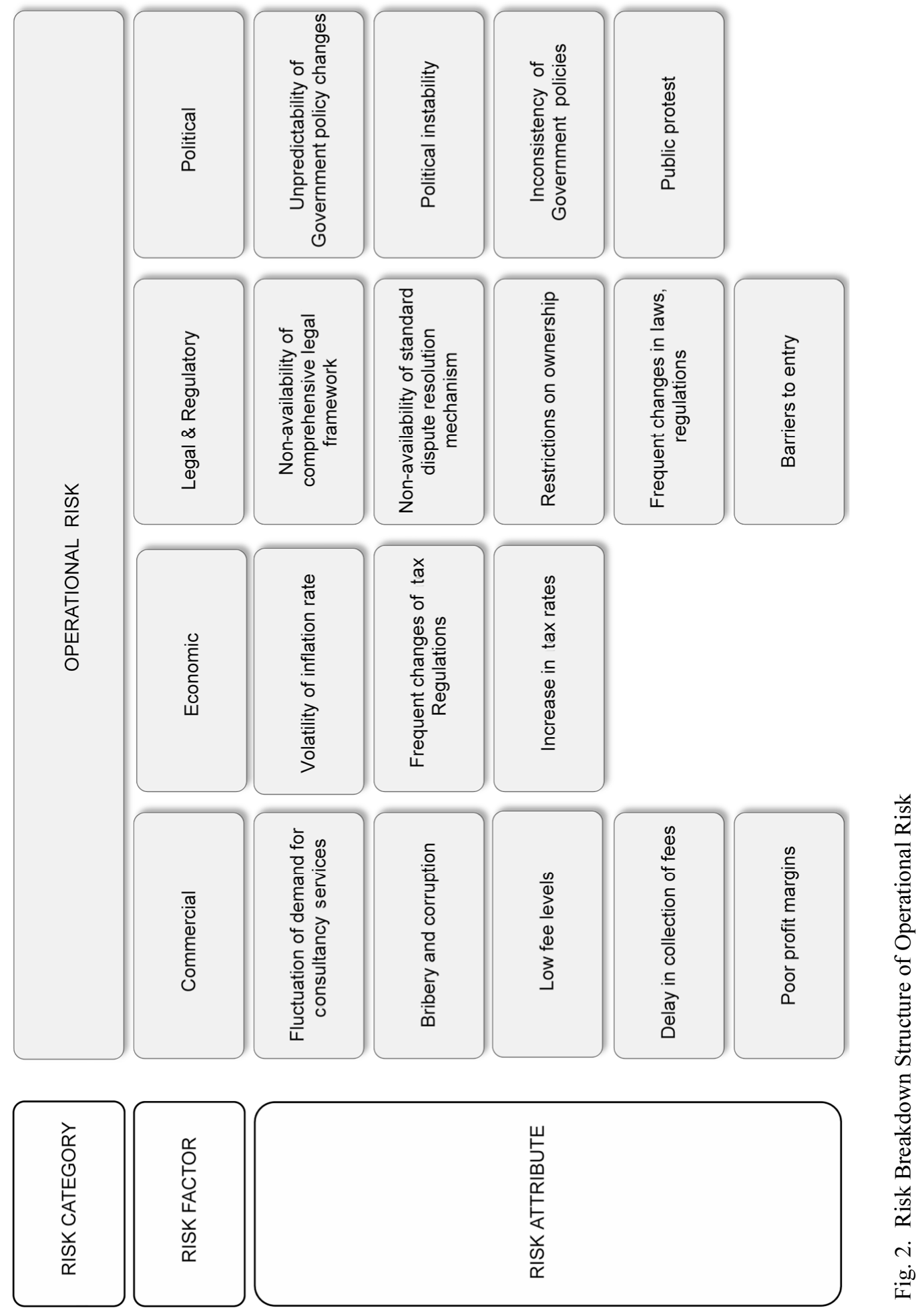




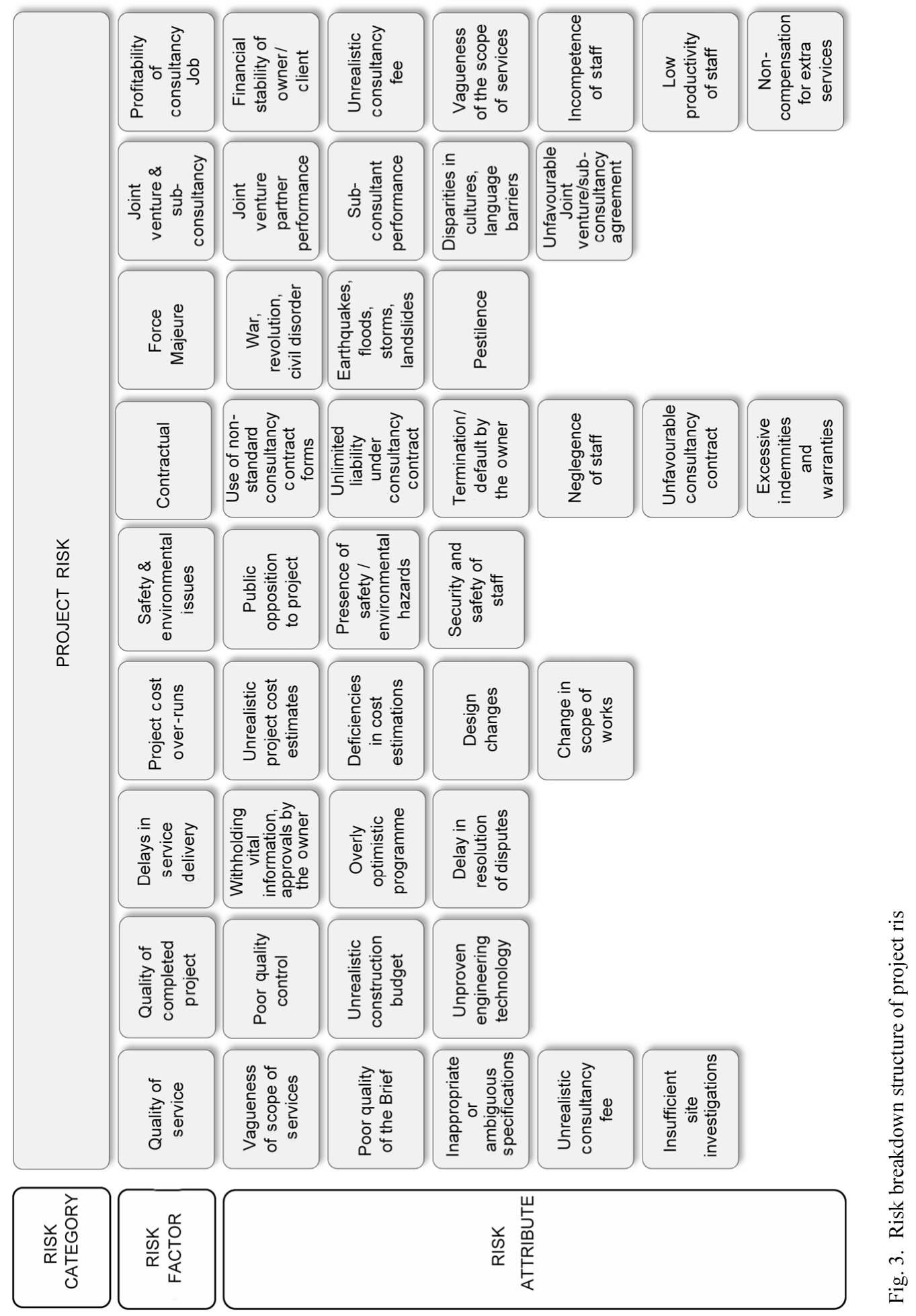



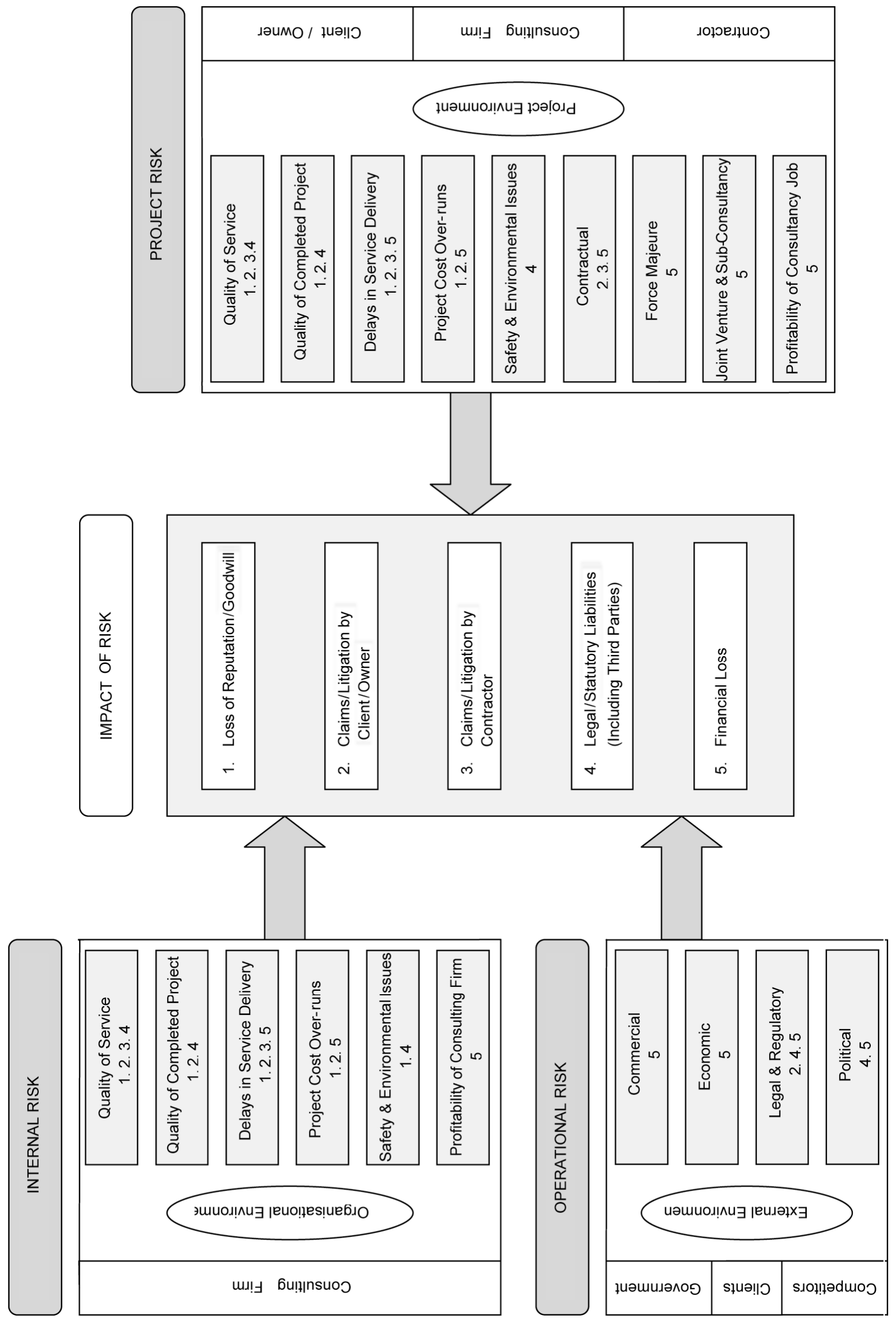

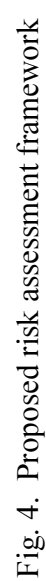


Table 5. Matrix for generating research findings

\begin{tabular}{|c|c|c|c|c|c|c|c|c|}
\hline & \multirow{2}{*}{ Merged Research Findings } & \multirow{2}{*}{ Relevant Cases } & \multicolumn{6}{|c|}{ Research Question } \\
\hline & & & 1 & 2 & 3 & 4 & 5 & 6 \\
\hline I & $\begin{array}{l}\text { There is a trend of escalating risk in the consulting } \\
\text { industry in general. }\end{array}$ & $\begin{array}{c}1,2,3,4,5,6,7,8,9,10,11 \\
12,13,14\end{array}$ & $\mathrm{H}$ & $\mathrm{M}$ & $\mathrm{L}$ & $\mathrm{L}$ & $\mathrm{L}$ & $\mathrm{L}$ \\
\hline II & $\begin{array}{l}\text { Risk in non-standard consulting services includes } \\
\text { additional factors not prevalent in standard forms of } \\
\text { consulting services. }\end{array}$ & $\begin{array}{c}1,3,4,5,6,7,8,9,10,11 \\
12,13,14\end{array}$ & $\mathrm{H}$ & $\mathrm{M}$ & $\mathrm{L}$ & $\mathrm{L}$ & $\mathrm{L}$ & $\mathrm{L}$ \\
\hline III & $\begin{array}{l}\text { Overall risk level in non-standard forms of consulting } \\
\text { services is higher than in standard consulting services. }\end{array}$ & $\begin{array}{c}1,3,4,5,6,7,8,9,10,11 \\
12,13,14\end{array}$ & $\mathrm{H}$ & $\mathrm{M}$ & $\mathrm{L}$ & $\mathrm{L}$ & $\mathrm{L}$ & $\mathrm{L}$ \\
\hline IV & $\begin{array}{l}\text { Underlying major causes for higher level of risk } \\
\text { specific to non-standard forms of consulting services } \\
\text { are: } \\
\text { - Ill-defined scope of services and deliverables; } \\
\text { - Use of inappropriate consultancy contract forms; } \\
\text { - Unlimited liability of consultant, often required } \\
\text { by clients; } \\
\text { - Financial stability of the clients; } \\
\text { - Lack of mature legal/commercial framework; and } \\
\text { - Increasing complexity of construction project or- } \\
\text { ganisations. }\end{array}$ & $\begin{array}{c}1,3,4,5,7,8,9,10,11,12 \\
13,14\end{array}$ & $\mathrm{M}$ & $\mathrm{H}$ & $\mathrm{L}$ & $\mathrm{L}$ & $\mathrm{L}$ & $\mathrm{L}$ \\
\hline $\mathrm{V}$ & $\begin{array}{l}\text { Most appropriate classification of Risk Categories in } \\
\text { non-standard forms of consulting services are: } \\
\text { - Internal Risk; } \\
\text { - Operational Risk; and } \\
\text { - Project Risk. }\end{array}$ & $1,2,3,4,5,6,8,9,10,11,12$ & $\mathrm{~L}$ & $\mathrm{~L}$ & $\mathrm{H}$ & $\mathrm{M}$ & $\mathrm{M}$ & $\mathrm{L}$ \\
\hline VI & $\begin{array}{l}\text { Most appropriate Risk Factors under each Risk Cate- } \\
\text { gory in non-standard forms of consulting services are } \\
\text { depicted in Figures } 1,2 \text { and } 3 \text {. }\end{array}$ & $1,2,3,4,5,6,8,9,10,11,12$ & $\mathrm{~L}$ & $\mathrm{~L}$ & $\mathrm{M}$ & $\mathrm{H}$ & $\mathrm{M}$ & $\bar{M}$ \\
\hline VII & $\begin{array}{l}\text { Most appropriate Risk Attributes under each Risk } \\
\text { Factor in non-standard forms of consulting services } \\
\text { are depicted in Figures } 1,2 \text { and } 3 \text {. }\end{array}$ & $1,2,3,4,5,6,8,9,10,11,12$ & $\mathrm{~L}$ & $\mathrm{~L}$ & $\mathrm{M}$ & $\mathrm{M}$ & $\mathrm{H}$ & $\bar{M}$ \\
\hline VIII & $\begin{array}{l}\text { Primary modes of impact of risk are: } \\
\text { - Loss of reputation and/or goodwill; } \\
\text { - Claims/litigation by client/owner; } \\
\text { - Claims/litigation by contractor; } \\
\text { - Legal/Statutory liabilities (including Third Par- } \\
\text { ties); and } \\
\text { - Financial loss. }\end{array}$ & $\begin{array}{c}1,2,3,4,5,7,8,9,10,11 \\
12,13,14\end{array}$ & $\mathrm{~L}$ & $\mathrm{~L}$ & $\mathrm{~L}$ & $\mathrm{M}$ & $\mathrm{M}$ & $\mathrm{H}$ \\
\hline
\end{tabular}

Note: H - High Importance; M - Medium Importance; L - Low Importance.

Source: Adapted from "Multiple Case Study Analysis" by Robert E Stake (2006)

The limitations of this simplified rating have been discussed by Ward (1997). A number of sophisticated methodologies are available for this purpose; one being Fuzzy Associative Memories developed by Tah and Carr (2001).

All Risk Factors/Attributes under each Risk Category are to be ranked according to their risk ratings which are influenced by the specific setting of the consultancy commission under consideration. A manageable number of highest ranking Risk Factors/Attributes are to be selected for the final phase of risk management, viz. risk response that encompasses risk response planning, risk allocation and risk monitoring. The risk response process is further facilitated by the application of proposed Risk Assessment Framework in predicting the potential impact of significant risks.

\subsection{Demonstration of the application of the risk assessment framework}

In order to demonstrate its application, proposed Framework was applied to a number of consulting firms that did not participate in the development of the Framework. One of these test cases is presented below:

Background - This engineering consultant is a leading international firm providing services worldwide. The Firm is specialised in ports and its business focus is on planning, design and development of world-class port facilities. The project is located within the port of Colombo, Sri Lanka, and comprised construction of a $940 \mathrm{~m}$ long container wharf, a $180 \mathrm{~m}$ passenger wharf, terminal building and ancillary facilities. The project costing US\$ 228 million was implemented through a 30 year Build-Operate-Transfer (BOT) concession. The client is the concessionaire company which is a consortium of Sri Lanka Ports Authority, three international financing institutions and few large private companies. 
Overview of the Organisational environment of the Consulting Firm - This is an international firm with substantial resources including experienced team of technical and allied staff at its disposal. The Firm has extensive experience in non-standard forms of services and operates an effective Quality Assurance system. Their experience, together with state-of-the-art technological resources enables the Firm to provide high quality services. Risk management function is handled by a senior manager. The Firm maintains a substantial Professional Indemnity insurance cover.

Overview of the External environment - The Firm had been facing competition from a number of international consulting firms. The global economic climate was unfavourable with high inflation, volatile exchange rates and high interest rates. In the host country, political stability was not considered a major concern, but the security situation was a concern.

Overview of the Project environment - The client was a consortium of reputed organisations, hence financial stability of the client was not a concern. The Firm had to offer a competitive fee to secure the consultancy contract. The Civil contractor was a reputed international company. One major concern was the insufficient site investigations, which could lead to major design changes. Although the brief was comprehensive, unforeseen changes to the scope of the consultant's service without adjustment to the fees was likely. The project site was located within a high security zone. The consultancy agreement was based on FIDIC White Book with appropriate modifications. The liability of the consultant was limited to $100 \%$ of the fees.

Application of the Risk Assessment Framework to the Firm - Ensuing risks from each of the 74 Risk Attributes were carefully assessed and rated for its relevance and significance in the context of the Organisational, External and Project environments, using the methodology outlined above. Out of the 74 Risk Attributes, 12 highest ranking Attributes comprising of one from Internal Risks, four from Operational Risks and seven from Project Risks were selected for the final phase of risk management and the remaining 62 were dropped (Table 6).

Consequently, final phase of risk management viz. risk response could focus on these 12 significant Risk Attributes and their potential impacts.

\section{Conclusions}

\section{Key findings}

The three objectives outlined in section 2 have been addressed in this research. Key findings are summarised as follows:

(i) There is a discernible trend of escalation of risk level in the engineering consulting industry. This trend is reflected in the significant rise in claims, as also observed by Hanna (2007). This finding was affirmed by all 14 Cases;

(ii) Risk in non-standard forms of consulting services is influenced by additional factors not prevalent in standard consulting services. This finding was supported in all cases except for one. Consultants are increasingly likely to have contractors/concessionaires/ financiers as their clients, instead of owners of projects;

(iii) Overall risk level in non-standard forms of consulting services is higher than in standard consulting services. Except for one, all other Cases affirmed this finding, which is corroborated by Yisa and Edwards (2002);

Table 6. Outcome of the application of Risk Assessment Framework to a test Case

\begin{tabular}{|c|c|c|c|c|c|}
\hline \multirow{2}{*}{$\begin{array}{l}\text { Risk attributes selected for risk } \\
\text { management }\end{array}$} & \multicolumn{5}{|c|}{ Potential impact of risk } \\
\hline & $\begin{array}{c}\text { Loss of Reputation/ } \\
\text { Goodwill }\end{array}$ & $\begin{array}{l}\text { Claims/Litigation } \\
\text { by Client/Owner }\end{array}$ & $\begin{array}{l}\text { Claims/Litigation } \\
\text { by Contractor }\end{array}$ & $\begin{array}{l}\text { Legal/Statutory } \\
\text { Liabilities }\end{array}$ & $\begin{array}{l}\text { Financial } \\
\text { Loss }\end{array}$ \\
\hline Poor coordination with other parties & \begin{tabular}{l|l}
$\bullet$ & \\
\end{tabular} & $\bullet$ & $\bullet$ & & $\bullet$ \\
\hline Low fee levels & & & & & $\bullet$ \\
\hline Frequent changes in Laws, Regulations & & $\bullet$ & & $\bullet$ & $\bullet$ \\
\hline $\begin{array}{l}\text { Unpredictability of Government policy } \\
\text { changes }\end{array}$ & & & & $\bullet$ & • \\
\hline Inconsistency of Government policies & & & & $\bullet$ & $\bullet$ \\
\hline Insufficient site investigations & $\bullet$ & $\bullet$ & $\bullet$ & $\bullet$ & \\
\hline Overly optimistic programme & $\bullet$ & $\bullet$ & $\bullet$ & & $\bullet$ \\
\hline Design changes & $\bullet$ & $\bullet$ & & & $\bullet$ \\
\hline Change in scope of Works & $\bullet$ & $\bullet$ & & & $\bullet$ \\
\hline $\begin{array}{l}\text { Presence of safety/environmental haz- } \\
\text { ards }\end{array}$ & & & & $\bullet$ & \\
\hline Security and safety of staff & & & & $\bullet$ & \\
\hline Non-compensation for extra Services & & & & & $\bullet$ \\
\hline
\end{tabular}


(iv) Underlying major causes for higher level of risk specific to non-standard forms of consulting services are:

-Ill-defined scope of services and deliverables;

- Use of inappropriate consultancy contract forms;

- Unlimited liability of consultant, often required by clients;

-Financial stability of the clients;

- Lack of mature legal/commercial framework;

- Increasing complexity of construction project organisations.

Twelve cases contributed to these findings;

(v) A hierarchical Risk Breakdown Structure comprising of three Risk Categories, 19 Risk Factors and 74 Risk Attributes, as depicted in Figures 1, 2 and 3 is found to be most appropriate for classification of risks in non-standard forms of consulting services. Eleven cases contributed to this finding;

(vi) Primary modes of impact of risk on consulting companies under non-standard forms of consulting services were identified in 13 Cases. The most serious impacts are:

- Loss of reputation and/or goodwill;

- Claims/litigation by client/owner;

- Claims/litigation by contractor;

- Legal/Statutory liabilities (including liabilities to Third Parties); and

-Financial loss.

Overall, the loss of reputation and/or goodwill is rated as the most important, in terms of potential long term adverse impact on consultants. This finding is in agreement with Ewing et al. (1999) who emphasised the importance of corporate reputation in professional engineering firms;

(vii) To a large extent the Risk Factors/Risk Attributes are concentrated around design office based activities that underline the importance of the design function in an engineering consulting organisation. This finding is corroborated by Tang et al. (2009) and $\mathrm{Ng}$ and Chow (2004).

\section{Significance and usefulness of the research}

In a rapidly changing operating environment, orderly assessment of escalating risk is a challenge to any engineering consulting organisation. In any case, only limited methodology is available for assessing the risks associated with non-standard forms of consulting services. This paper has explored the genesis of underlying risks in such consulting services and presented an exhaustive Risk Assessment Framework that would fill this knowledge gap.

Development of a Framework that provides a functional tool for efficient assessment of risks in new business frontiers is expected to provide an impetus for engineering consulting industry to improve their risk management capability. At firm level, efforts on the risk management function, particularly in developing risk responses, could be focused on limited number of significant Risk Factors/Risk Attributes selected through the application of the proposed Risk Assessment Framework.
Although developed in the context of consulting firms operating in the Asian region, the proposed Risk Assessment Framework is envisaged to be applicable to the engineering consulting industry worldwide.

\section{Limitations of the research}

The risk in engineering consulting is intangible, and the inputs to this research are to some extent subjective. Furthermore, the research relies on the quality of opinions and judgment of the senior management of the participating consulting firms.

\section{References}

Artto, K. A. 1997. Focusing on risk response development and risk measures to be taken - can risk estimating even be skipped in an RM application? in Kähkönen, K.; Artto, K. A. E. (Eds.). Managing risks in projects. London: FN Spon, 353-361.

Barber, R. B. 2005. Understanding internally generated risks in projects, International Journal of Project Management 23: 584-590.

http://dx.doi.org/10.1016/j.ijproman.2005.05.006

Ewing, M. T.; Caruana, A.; Loy, E. R. 1999. Corporate reputation and perceived risk in professional engineering services, Corporate Communications: An International Journal 4(3): 121-128.

Halman, J. I. M.; Weijden, P. M. van der. 1997. In search of best practices in risk management, in Kähkönen, K.; Artto, K. A. E. (Eds.). Managing risks in projects. London: FN Spon, 31-40.

Hanna, A. S. 2007. Risk allocation and increased claims in the construction industry, Journal of Professional Issues in Engineering Education \& Practice ASCE 133(1): 43-44. http://dx.doi.org/10.1061/(ASCE)10523928(2007)133:1(43)

Hansen, K. L.; Millar, J. E. 1997. Constructing reasonably believable edifices: lessons from software, implications for construction, in Kähkönen, K.; Artto, K. A. E. (Eds.). Managing risks in projects. London: FN Spon, 255-264.

International Federation of Consulting Engineers. 1997. Risk management manual. FIDIC, Geneva, and DPIC Companies Inc., California, U.S.

Jaafar, M.; Aziz, A. R. A.; Wai, A. L. S. 2008. Marketing practices of professional engineering consulting firms: implement or not to implement?, Journal of Civil Engineering and Management 14(3): 199-206. http://dx.doi.org/10.3846/1392-3730.2008.14.17

Kardon, J. B. 2005. Concept of "care" in engineering, Journal of Performance of Constructed Facilities ASCE 9(3): 256-260. http://dx.doi.org/10.1061/(ASCE)08873828(2005)19:3(256)

Kim, S.-G. 2010. Risk performance indexes and measurement systems for mega construction projects, Journal of Civil Engineering and Management 16(4): 586-594. http://dx.doi.org/10.3846/jcem.2010.65

Ng, S. T.; Chow, L.-K. 2004. Framework for evaluating the performance of engineering consultants, Journal of Professional Issues in Engineering Education and Practice ASCE 20(4): 147-161.

Ojo, S. O.; Aina, O.; Adeyemi, A. Y. 2011. A comparative analysis of the performance of traditional contracting and design-build procurements on client objectives in Nigeria, 
Journal of Civil Engineering and Management 17(2): 227-233. http://dx.doi.org/10.3846/13923730.2011.574449

Project Management Institute. 2008. A guide to the project management body of knowledge, (PMBOK Guide). Project Management Institute Inc., Newton Square, Pennsylvania, U.S.

Rahman, M. M.; Kumaraswamy, M. M. 2004. Contracting relationship trends and transitions, Journal of Management in Engineering ASCE 20(4): 147-161. http://dx.doi.org/10.1061/(ASCE)0742597X(2004)20:4(147)

Stake, R. E. 2006. Multiple case study analysis. New York: The Guilford Press.

Tah, J. H. M.; Carr, V. 2001. Knowledge-based approach to construction project risk management, Journal of Computing in Civil Engineering ASCE 15(3): 170-177. http://dx.doi.org/10.1061/(ASCE)08873801(2001)15:3(170)

Tang, S. K.; Aoieong, R. T. M.; Tsui, C. S. L. 2009. Quality culture auditing for engineering consultants, Journal of Management in Engineering ASCE 25(4): 204-213. http://dx.doi.org/10.1061/(ASCE)0742597X(2009)25:4(204)

WM Sarath C PIYADASA. Doctoral student at the Department of Construction, Engineering and Infrastructure Management, School of Engineering and Technology, Asian Institute of Technology, Thailand. At present he is a Contract Specialist attached to a leading international consulting firm. He has extensive experience as a consulting engineer and in the management of consulting companies. He holds Master of Engineering in Construction Management degree from University of Moratuwa, Bachelor of Engineering (Honours) from University of Peradeniya and Bachelor of Laws from Open University of Sri Lanka. He is a Fellow of the American Society of Civil Engineers, Member of the Institution of Civil Engineers UK, Chartered Engineer and International Professional Engineer. His research interests include construction disputes, risk management and optimization of consultancy service delivery process.

Bonaventura H. W. HADIKUSUMO. An Associate Professor of Construction, Engineering and Infrastructure Management at the School of Engineering and Technology, Asian Institute of Technology, Thailand. He holds a PhD in Construction Management from the University of Hong Kong and Master of Engineering from Asian Institute of Technology. He has published extensively in international journals and authored book chapters. He is serving as a member of the Advisory Board of an international journal and reviewer of international journals. He is very active in teaching and conducting research in Project Management in Southeast Asia particularly in Thailand, Indonesia and Vietnam. His research interests are management of construction organizations, project management and construction site safety. 